\title{
Studies on the physico-chemical characteristics, antioxidant activity and juice organic compound composition in Azerbaijan wild pomegranate fruits
}

\author{
Aydan M. Zeynalova ${ }^{1}$ \\ Eldar N. Novruzov \\ Institute of Botany, Azerbaijan National Academy of Sciences, \\ Badamdar 40, Baku, AZ1004, Azerbaijan \\ Biancaelena Maserti \\ Institute for Sustainable Plant Protection (IPSP), CNR, Italy
}

\begin{abstract}
Pomegranate fruit represents a rich source of bioactive components. These phytochemicals accumulate in different parts of the fruits, such as the exocarp, mesocarp, seeds and arils. Wild type species have been suggested to contain high amounts of potential bioactive compounds. Therefore a field campaign in eight different areas of Azerbaijan has been performed to collect pomegranate samples. In this work, the physical properties and the antioxidant capacities of peels, juice, flowers and leaves of the each different pomegranate accessions of eight wild pomegranate accessions grown under different conditions in different regions of Azerbaijan are reported, together with the identification and quantification of the phenolic compounds and the anthocyanin composition present in different parts of one pomegranate accessions. The study of bioactive components in P.g.1 showed that cyanidin-3,5diglucoside (34.65\%) was the predominant anthocyanin pigment of juice and -epicatechin was the most abundant polyphenol $(67.23 \mathrm{mg} / \mathrm{kg})$ in pomegranate exocarp. The results of this study will contribute to the assessment of wild pomegranate biodiversity and allow to detect samples with high quality characteristics of fruits for potential commercial production of medicinal and cosmetic products, food additives from this plant.
\end{abstract}

Key Words: Punica granatum L., free radical scavenger, phenolic compounds, anthocyanins

\section{INTRODUCTION}

Currently, worldwide, active work is underway to identify new sources of bio-antioxidants. These studies are associated with the growth and development of many serious diseases such as cancer, stroke, type 2 diabetes, cardiovascular and neurodegenerative diseases. The concurrent cause of these diseases is the oxidative stress, due to the increase of production of reactive forms of oxygen, nitrogen, including free radicals and the inability of the body to neutralize them [Sharova, 2016].

For a compound to be defined as an antioxidant it must satisfy two basic conditions: (1) When present at low concentration relative to the substrate to be oxidized, it can delay or prevent autoxidation or free radical-mediated oxidation; (2) The resulting radical formed after scavenging must be stable in order to interrupt the oxidation chain reaction [Rosenblat, Aviram, 2006].

Plant polyphenols are an important class of antioxidants. Phenolic compounds are excellent oxygen radical scavengers because the electron reduction potential of the phenolic radical is lower than that of oxygen radicals. Therefore, phenolic compounds can scavenge reactive oxygen intermediates thus preventing further oxidative reactions [Ainsworth, Gillespie, 2007].

The bioactive components accumulate in different parts of the pomegranate fruits, such as the exocarp, mesocarp, seeds and arils [Viuda-Martos et al., 2010]. Many investigators [De Nigris et al., 2005] have reported that pomegranate juice has a free radical scavenger and potent antioxidant capacity. These beneficial effects of the pomegranate juice were attributed to the antioxidant properties of pomegranate polyphenols and sugar containing polyphenolic tannins and anthocyanins [Elfalleh et al., 2011].

Physical and chemical properties, and also the antioxidant activity of wild pomegranate have been evaluated in Greece [Drogoudi, Tsipouridis, 2005], Iran [Akbarpour et al., 2009], Croatia [Gadže et al., 2010]. Such systemic works are lacking of information about wildgrowing pomegranates largely distributed in the territory of Azerbaijan. Thus, the purposes of this study were: a) to study the physical properties of the eight wild pomegranate accessions collected in different regions of Azerbaijan; b) to identify and quantify the phenolic compounds and the anthocyanin composition present in different parts of one pomegranate accessions; c) to investigate the antioxidant capacities of different tissues of the eight pomegranate accessions. 


\section{MATERIAL AND METHODS}

Sample preparation. Ripe fresh fruits were collected from eight different collection sites of Azerbaijan Republic: Khizi, Siyazan, Sheki, Ismayilli, Yevlakh, Agsu Mountain Pass, Agsu and Gokchay district (Table 1). The fruits from Khizi and Siyazan district were collected at harvest maturity in the beginning of October 2018. The fruits of the other six accessions were collected at the end of September.
Each fruit was weighed individually, then the arils, peel and calyx membranes were manually removed and weighed. Weights were recorded on an electronic balance (Mettler Toledo, Switzerland) with an accuracy of $0.01 \mathrm{~g}$. Length and width of the fruit and calyx were measured with a digital Vernier calliper. Measurements were replicated three times for each fruit. The pomegranate arils were manually separated from the exocarp and mesocarp, and total aril weight (TAW) per fruit was

Table 1. Geographic data of eight wild pomegranate, collected from different regions of Azerbaijan

\begin{tabular}{lcccc}
\hline \hline \multicolumn{1}{c}{ Collection site } & Code & Latitude North & Longitude West & Altitude (m) \\
\hline $\begin{array}{l}\text { Khizi district } \\
\text { (Sayadlar village) }\end{array}$ & P.g.1* & $40^{\circ} 52^{\prime} 43.91^{\prime \prime}$ & $49^{\circ} 11^{\prime} 18.73^{\prime \prime}$ & 200 m.a.s.l \\
$\begin{array}{l}\text { Siyazan district } \\
\text { (Siyazan-Mashrifroad) }\end{array}$ & P.g.2 & $41^{\circ} 04^{\prime} 45.468^{\prime \prime}$ & $49^{\circ} 00^{\prime} 14.454^{\prime \prime}$ & 230 m.a.s.1 \\
$\begin{array}{l}\text { Sheki region } \\
\text { (Kichik Dahna village) }\end{array}$ & P.g.3 & $40^{\circ} 59^{\prime} 42.78^{\prime \prime}$ & $47^{\circ} 7^{\prime} 10.48^{\prime \prime}$ & 280 m.a.s.l \\
$\begin{array}{l}\text { Ismayilli district } \\
\text { (Balikli village) }\end{array}$ & P.g.4 & $40^{\circ} 45^{\prime} 2.82^{\prime \prime}$ & $48^{\circ} 3^{\prime} 47.15^{\prime \prime}$ & 540 m.a.s.1 \\
$\begin{array}{l}\text { Yevlakh district } \\
\text { Agsu mountain pass }\end{array}$ & P.g.5 & $40^{\circ} 44^{\prime} 49.22^{\prime \prime}$ & $47^{\circ} 12^{\prime} 14.81^{\prime \prime}$ & 60 m.a.s.l \\
$\begin{array}{l}\text { Agsu district } \\
\text { Gokchay district }\end{array}$ & P.g.6 & $40^{\circ} 35^{\prime} 9.40^{\prime \prime}$ & $48^{\circ} 25^{\prime} 24.33^{\prime \prime}$ & 420 m.a.s.l \\
\hline
\end{tabular}

Note : * Sample included in chemical analyses

The fruits of pomegranates were divided and the outer leathery skin covering arils were eliminated manually. Then, the juice was obtained from arils by mechanical press, and stored at $-80^{\circ} \mathrm{C}$. The peel of fruits were dried at $40^{\circ} \mathrm{C}$ and crashed with a grinding mill. Three fruits for each sampling area were analyzed.

Chemicals and reagents. Potassium phosphate, phosphoric acid, 2,2-diphenyl-1-picryl-hydrazil (DPPH) reagent were purchased from Sigma-Aldrich (St. Louis, MO, USA). All standards of anthocyanins (delphinidin 3-glucoside and 3,5-diglucoside, cyaniding 3-glucoside, 3,5-diglucoside, pelargonidin 3-glucoside, 3,5-diglucoside) and phenolic standards (as well as HPLC grade solvents) were also obtained from Sigma- Aldrich (St. Louis, MO, USA).

Physical properties. Morphological measurements of fruits were carried out on samples of 5 fruits per accessions. The following characteristics were studied: Fruit length (FL); Fruit width (FW); Fruit weight $\left(\mathrm{FW}^{*}\right)$; Aril length (AL); Aril width (AW); Total aril weight (TAW); Numbers of aril per fruit (AN); Crown neck length (CNL); Number of calyx sepals (CSN); Calyx sepals length (CSL); Aril ratio (AR); Calyx Index (CI); Juice yield (JY) (Table 2). recorded.

Calyx index (CI, \%) was determined as the ratio of calyx length and total fruit length.

The aril ratio was calculated following the formula:

$$
\text { Aril ratio }=(\text { total aril weight } / \text { fruit weight }) \times 100 \%
$$$$
\text { [Martínez et al., 2006]. }
$$

Fruit juice content was determined by extracting of juice from three fruit of each accessions and expressed as volume of juice per $20 \mathrm{~g}$ of arils per fruit.

Sensory evaluation. Fruit and aril colours were determined based on the coloration scale. The sensory evaluation was carried out by four members of the laboratory of Institute of Botany, aged 24-60 years. All panel lists had significant experience in sensory evaluation of fruits and fruit juices. They were asked to assess the colour and taste of the whole fruits and arils.

Metabolite analyses. The identification and quantification of individual phenolic compounds and anthocyanins in the exocarp, mesocarp and aril juice were determined in a single sample (P.g.1), selected on the basis of the morphological characteristics of the fruit and distribution place. 


\section{PLANT \& FUNGAL RESEARCH}

Table 2. Physical characteristics of the fruits of eight wild pomegranate accessions.

\begin{tabular}{|c|c|c|c|c|c|c|c|c|c|c|c|c|c|}
\hline Code & $\begin{array}{c}\mathrm{FL} \\
(\mathrm{mm})\end{array}$ & $\begin{array}{c}\text { FW } \\
(\mathrm{mm})\end{array}$ & $\begin{array}{c}\mathrm{FW}^{*} \\
(\mathrm{~g})\end{array}$ & $\mathrm{AL}(\mathrm{mm})$ & $\begin{array}{c}\mathrm{AW} \\
(\mathrm{mm})\end{array}$ & $\begin{array}{c}\text { TAW } \\
(\mathrm{g})\end{array}$ & AN & $\begin{array}{l}\mathrm{CNL} \\
(\mathrm{mm})\end{array}$ & $\overline{\mathrm{CSN}}$ & $\begin{array}{c}\text { CSL } \\
(\mathrm{mm})\end{array}$ & $\begin{array}{l}\text { AR } \\
(\%)\end{array}$ & $\begin{array}{c}\mathrm{CI} \\
(\%)\end{array}$ & $\begin{array}{l}\text { Juice } \\
\text { yiled } \\
(\%)\end{array}$ \\
\hline & 41,33 & 47,66 & 59,00 & $8,67 \pm$ & $6,00 \pm$ & 31,33 & 150,33 & $7,67 \pm$ & $7,00 \pm$ & $9,00 \pm$ & 53,10 & 18,56 & 49,7 \\
\hline \multirow[t]{2}{*}{ P.g.1 } & $\pm 7,02$ & $\pm 13,32$ & $\pm 37,04$ & 0,44 & 0,67 & $\pm 22,50$ & $\pm 78,42$ & 1,11 & 0,67 & 0,67 & & & \\
\hline & 44,00 & 51,33 & 79,00 & $8,33 \pm$ & $5,67 \pm$ & 47,66 & 241,67 & $7,67 \pm$ & $6,33 \pm$ & $10,00 \pm$ & 97,21 & 17,43 & 67,2 \\
\hline \multirow[t]{2}{*}{ P.g.2 } & $\pm 11,53$ & $\pm 20,74$ & $\pm 49,03$ & 0,44 & 0,44 & $\pm 38,53$ & $\pm 178,37$ & 1,78 & 0,44 & 0,67 & & & \\
\hline & 37,66 & 44,33 & 49,33 & $8,00 \pm$ & $5,67 \pm$ & 29,33 & 127 & $6,67 \pm$ & $7,00 \pm$ & $9,33 \pm$ & 59,46 & 17,71 & 69,6 \\
\hline \multirow[t]{2}{*}{ P.g.3 } & $\pm 12,50$ & $\pm 12,90$ & $\pm 43,50$ & 0 & 0,44 & $\pm 24,58$ & $\pm 106,15$ & 2,22 & 0,67 & 0,89 & & & \\
\hline & 31,66 & 28,66 & 37,33 & $8,00 \pm$ & $4,67 \pm$ & 22,33 & 168,67 & $6,33 \pm$ & $6,00 \pm$ & $10,67 \pm$ & 59,82 & 19,99 & 35,4 \\
\hline \multirow[t]{2}{*}{ P.g.4 } & $\pm 7,64$ & $\pm 22,50$ & $\pm 15,28$ & 0 & 0,44 & $\pm 9,71$ & $\pm 53,08$ & 1,78 & 0,67 & 0,44 & & & \\
\hline & 41,00 & 48,66 & 63,67 & $8,00 \pm$ & $5,33 \pm$ & 36,33 & 210,67 & $5,00 \pm$ & $6,00 \pm$ & $8,67 \pm$ & 57,06 & 12,20 & 72,5 \\
\hline \multirow[t]{2}{*}{ P.g. 5} & $\pm 6,56$ & & $\pm 24,58$ & 0 & & $\pm 13,01$ & $\pm 53,72$ & 1,33 & 0,67 & 1,111 & & & \\
\hline & 35,00 & 41,66 & 49,67 & $7,67 \pm$ & $5,67 \pm$ & 28,66 & 142,33 & $8,3 \pm$ & $6,33 \pm$ & $8,00 \pm$ & 57,70 & 23,71 & 78,3 \\
\hline \multirow[t]{2}{*}{ P.g.6 } & $\pm 10,00$ & $\pm 14,50$ & $\pm 45,08$ & 0,44 & 0,44 & $\pm 30,44$ & $\pm 144,98$ & 1,11 & 0,44 & 0,67 & & & \\
\hline & 37,33 & 42,00 & 45,67 & $5,67 \pm$ & $4,00 \pm$ & 29,00 & 309,67 & $8,33 \pm$ & $6,00 \pm$ & $8,33 \pm$ & 63,50 & 22,31 & 63,4 \\
\hline \multirow[t]{2}{*}{ P.g.7 } & $\pm 6,81$ & $\pm 8,00$ & $\pm 24,54$ & 1,11 & 0,67 & $\pm 18,68$ & $\pm 76,29$ & 1,11 & 0,67 & 0,89 & & & \\
\hline & 58,00 & 59,00 & 99,33 & $5,67 \pm$ & $3,67 \pm$ & 59,33 & 471 & $8,00 \pm$ & $7,00 \pm$ & $9,67 \pm$ & 59,73 & 13,79 & 74,3 \\
\hline P.g. 8 & $\pm 2,65$ & $\pm 5,57$ & $\pm 35,23$ & 1,11 & 0,44 & $\pm 17,47$ & $\pm 129,99$ & 0,67 & 0,67 & 1,78 & & & \\
\hline
\end{tabular}

Note: All data were expressed as means \pm SD.

$p H$, total soluble solids. The $\mathrm{pH}$ measurements were performed using a digital $\mathrm{pH}$ meter (827 $\mathrm{pH}$ Lab, Metrohm, Swiss). Total soluble solids (TSS) were determined with the juice obtained from each subsample using a refractometer (model), calibrated using distilled water and reported as degree $\circ$ Brix at $21^{\circ} \mathrm{C}$.

Identification and quantification of phenolic compounds and anthocyaninsby HPLC analyses. The analytical separation and determination were performed using Varian LC/MS (US Ser. No. 05755). The identification of the phenolic acids from the chromatograms of the plant extracts was carried out by comparing the retention time with the corresponding standards purchased from Sigma Aldrich.

To the freshly squeezed pomegranate juice $(500 \mathrm{ml})$ $1 \mathrm{ml}$ of $1 \% \mathrm{HCl}$, was added to precipitate the debris. Then the solution was centrifuged and distilled in a rotary evaporator at $40^{\circ} \mathrm{C}$ under vacuum. $200 \mathrm{ml}$ of ethanol and $1 \mathrm{ml}$ of $1 \% \mathrm{HCl}$ stored in the refrigerator for 24 hours was added to the remaining mass. Next, the juice before passing through the $\mathrm{C} 18$ mini cartridge was again dried in a rotary evaporator at $40^{\circ} \mathrm{C}$ under vacuum and then dissolved in $2 \mathrm{ml}$ double-distilled water.

$20 \mathrm{ml}$ methanol was added to $10 \mathrm{~g}$ sample and stored in a refrigerator at $4^{\circ} \mathrm{C}$ for 12 hours for peel phenols and anthocyanins extraction. The extracts were then filtered through a Buchner funnel and dried in a rotary evaporator at $40^{\circ} \mathrm{C}$ under vacuum, before passing through a C18 mini cartridge.

Mini-columns $\mathrm{C} 18$ containing chains of $\mathrm{C} 18$ bound on silicon hydroxide, retain hydrophobic organic compounds (for example, anthocyanins, phenols), there by allowing the washing of distilled water with sugars and organic acids, washing the remaining pigments with ethyl acetate, and removing the remaining phenolic acids the anthocyanins are washed off with methanol.

The methanoland ethyl acetate fractions were dried in a rotary evaporator and then dissolved in $80 \%$ ethanol. Thus, the samples for HPLC were ready for analysis. The concentration of phenolic compounds and anthocyanins were calculated using the following equation (1).

$$
Y=\frac{\mathrm{CxV}}{\mathrm{W}} \mathrm{x}
$$

Equation 1. C - concentration of phenolic compounds in the sample (mg); V - volume of total extract (ml); $\mathrm{W}$ - weight of the sample of the plant taken for analysis; $\mathrm{x}$-dilution.

Mobile phases. The gradient consisted of two eluents: $\mathrm{A}$ and B. For phenolic compounds, the eluents were as following:

A-water/phosphoric acid (99:0.2) and

B-acetonitrile/water/phosphoric acid (50:49.8:0.2).

For anthocyanins: A-water/formic acid/acetonitrile (87:10:13) and B-water/formic acid/acetonitrile (40:10:50). The flow rate was $1.0 \mathrm{ml} / \mathrm{min}$.

Determination of antioxidant activities. The antioxidant activities of the methanol extracts of pomegranate exocarp, mesocarp and fresh aril juice were determined spectrophotometrically using $\mathrm{DPPH} \bullet$ reagent (SigmaAldrich, St. Louis, MO, USA).

The DPPH radical scavenging activity (RSA) of pomegranate extracts was quantified according to the 
method reported by Brand-Williams et al. [1995]. Triplicate analyses were performed for each extract.

For DPPH radical scavenging assay, $10 \mu \mathrm{L}$ of pomegranate juice, methanolic extract of exocarp and mesocarp were mixed with $940 \mu \mathrm{L}$ of water and $50 \mu \mathrm{L}$ of methanolic DPPH radical (2 mM). After leaving for 30 minutes in the thermomixer (Eppendorf Thermomixer Comfort) at $25-27^{\circ} \mathrm{C}$, the absorbance was recorded at $517 \mathrm{~nm}$ using a UV visible spectrophotometer (Safas, Monaco).

The RSA was calculated as percentage DPPH discoloration using the following equation.

$$
R S A(\%)=[(A D P P H-A \text { Sample }) / A D P P H] \times 100
$$

where, A Sample is the absorbance of the solution containing the extract after $30 \mathrm{~min}$. and A DPPH is the absorbance of the DPPH solution devoid of extract.

Statistical Analysis. Statistical analysis was performed by Microsoft Excel 2007.

\section{RESULTS AND DISCUSSION}

Physical properties. The physical properties of eight studied pomegranate accessions are listed in Table 2. The average fruit weight of pomegranate accessions ranged from $37.33 \mathrm{~g}$ (P.g.4) to $99.33 \mathrm{~g}$ (P.g.8). Arils weight was significantly higher in P.g.8 (59.33). The total fruit length ranged from $31.66 \mathrm{~mm}$ (P.g.4) to 58.00 $\mathrm{mm}$ (P.g.8), and the width from 28,66 mm (P.g.4) to $59.00 \mathrm{~mm}$ (P.g.8), whereas aril length ranged from 5.67 (P.g.7, 8) to 8.67 (P.g.1), and the width from $3.67 \mathrm{~mm}$ (P.g.8) to $6.00 \mathrm{~mm}$ (P.g.1). Accessions also differed in calyx size which index varied from 13.79 (P.g.8) to 23.71 (P.g.7).The number of arils per fruit indicated that there is a significant difference among the accessions. The number of arils per fruit for P.g. 3 is 127 and 471 for P.g.8. Results indicated that P.g.8 has maximum mean of 471 arils per fruit.
Juice yield differed significantly and ranged from $35.4 \%$ to $78.3 \%$, with the lowest yield in P.g.4.

Some previous studies reported a wide variation among the juice content of 12 Iran cultivars from $20.18 \%$ to $59.83 \%$, whereas the juice content from Spanish pomegranate varieties ranged between 50.26\% and $64.17 \%$ [Akbarpour, Sharifani, 2009].

Sensory evaluation, $\mathrm{pH}$, total soluble solids. The organoleptic and chemical characteristics of the fruits are given in Table 3. The total soluble solid content was significantly higher in P.g.8 (17.48 ${ }^{\circ}$ Brix). $\mathrm{pH}$ is an important factor for color expression of anthocyanins, being these compounds more stable in acidic than alkaline or neutral medium. In acidic medium, there is a shift in anthocyanins chromophores equilibrium to the favyliumcation, the most stable anthocyanin form [Pavez, 2011; Hirth et al., 2014; Fernandes et al., 2017]. The juices of P.g.4, P.g. 5 and P.g. 8 were the most reddish due to their high anthocyanin pigment contents and low $\mathrm{pH}(2.23-2.35)$.

The fruit and aril colour were determined based on the coloration scale from cream to dark red colour. Pomegranate aril colour varies from whitish pink to pink-red, and the peel colour varies from yellowish pink to green red (Table 3).

Identification and quantification of phenolic compounds and anthocyanins by HPLC analyses. Currently, due to the growth of oncological diseases, the search for substances that have the ability to prevent or at least slow down the growth of cancer is of particular interest. In addition to their use in medical application, plant pigments are used in the food, textile, leather and metallurgical industries. They are especially valuable in the food industry like dyes and antioxidants. Therefore, the problem of finding pigment-containing sources, the development of a rational method and organization of the production of natural food dyes and food additives, as well as medical products at the present stage is very re-

Table 3. Some organoleptic and chemical characteristics of the fruits.

\begin{tabular}{lccccc}
\hline Code & Peel color & Aril color & Taste & $\begin{array}{c}\text { pH of aril } \\
\text { juice }\end{array}$ & $\begin{array}{c}\text { Total Soluble } \\
\text { Solid ('Brix) }\end{array}$ \\
\hline P.g.1 & Yellowish pink & Pink & Sour-Sweet & 2.44 & 15,42 \\
P.g.2 & Green-Red & Pink & Sour-Sweet & 2.67 & 15,05 \\
P.g.3 & Yellowish pink & Whitish pink & Sour-Sweet & 2.47 & 17,25 \\
P.g.4 & Pink & Pink-Red & Sour & 2.35 & 15,35 \\
P.g.5 & Yellowishpink & Pink-Red & Sour & 2.23 & 14,75 \\
P.g.6 & Yellowishpink & Pink & Sour-Sweet & 2.45 & 13,35 \\
P.g.7 & Green-Pink & Pink & Sour & 2.39 & 15,20 \\
P.g.8 & Pink & Pink-Red & Sour & 2.34 & 17,48 \\
\hline
\end{tabular}


Table 4. Phenolic compounds and anthocyanins from exocarp and aril juice in P.g. 1.

\begin{tabular}{lcccccccccc}
\hline Sample & $\begin{array}{c}\text { Dp-3.5- } \\
\text { digluc } \\
(\%)\end{array}$ & $\begin{array}{c}\text { Cy- } \\
\begin{array}{c}3.5- \\
\text { digluc } \\
(\%)\end{array}\end{array}$ & $\begin{array}{c}\text { Dp-3- } \\
\text { gluc } \\
(\%)\end{array}$ & $\begin{array}{c}\text { Pg- } \\
\begin{array}{c}3.5- \\
\text { digluc } \\
(\%)\end{array}\end{array}$ & $\begin{array}{c}\text { Cy-3- } \\
\text { gluc } \\
(\%)\end{array}$ & $\begin{array}{c}\text { Pg-3- } \\
\text { gluc } \\
(\%)\end{array}$ & $\begin{array}{c}+ \text { catechin } \\
(\mathrm{mg} / \mathrm{kg})\end{array}$ & $\begin{array}{c}\text {-epicatechin } \\
(\mathrm{mg} / \mathrm{kg})\end{array}$ & $\begin{array}{c}\text { quercetin } \\
(\mathrm{mg} / \mathrm{kg})\end{array}$ & $\begin{array}{c}\text { vanilline } \\
(\mathrm{mg} / \mathrm{kg})\end{array}$ \\
\hline Exocarp & 3.85 & 14.27 & 2.97 & 25.90 & 18.79 & 32.90 & 2.04 & 67.23 & 0.44 & 15.55 \\
Juice & 20.80 & 34.65 & 13.19 & 1.67 & 27.48 & 1.82 & 0.22 & 2.39 & 3.05 & 0.15
\end{tabular}

levant [Novruzov, 2010].

The levels of +catechin, -epicatechin, quercetin, vanilline, delphinidin-3.5-diglucoside (Dp-3.5-digluc), cyanidin-3.5-diglucoside (Cy-3.5-digluc), delphinidin3-glucoside (Dp-3-gluc), pelargonidin-3.5-diglucoside (Pg-3.5-digluc), cyanidin-3-glucoside (Cy-3-gluc), pelargonidin-3-glucoside (Pg-3-gluc) were determined using HPLC in pomegranate tissue of the accession P.g.1. Table 4 presents the concentration of individual phenolic compounds and anthocyanins in the exocarp and aril juice. Anthocyanins had the same profile as previously reported by Gil et al. [2000].

Phenolic compounds identified in pomegranate juice and peel were found in minor quantities except epicatechin and vanilline. As shown in the table, cyanidin-3.5-diglucoside (34.65\%) was the predominant anthocyanin pigment of juice. This same trend of anthocyanin content was also observed in wild accession from Croatia [Radunícet al., 2015] and Tunisian cultivars [Hasnaoui et al., 2011]. In contrast with our results, delphinidin-3,5-diglucoside was the major pigment in Iranian accessions [Mousavinejad et al., 2009]. Thus, regarding the anthocyanins concentration in juice, they follow the next order: cyanidin 3,5-di-O-glucoside, cyanidin-3-O-glucoside, delphinidin-3,5-diglucoside, delphinidin-3-glucoside, pelargonidin-3,5-diglucoside and pelargonidin-3-glucoside. Similar order was reported for cultivars grown in Georgia [Rajasekar et al., 2012]. However, this order was different for anthocyanins concentration of peel, where the lowest concentrations were observed for pelargonidin-3-glucoside and pelargonidin-3,5-diglucoside (32.9\% and $25.90 \%$ ).

In pomegranate exocarp the epicatechin was the most abundant monomeric polyphenol $(67.23 \mathrm{mg} / \mathrm{kg})$. However, in juice sample its concentration was significantly lower $(2.39 \mathrm{mg} / \mathrm{kg})$. Unlike our results, catechin (2.8-6.28 g/100 g) was the main phenolic compound of Iranian pomegranates juice [Cuccioloni et al., 2009].

Antioxidant activities. DPPH (2,2-diphenyl-1-picrylhydrazyl $\left(\mathrm{C}_{18} \mathrm{H}_{12} \mathrm{~N}_{5} \mathrm{O}_{6}, \mathrm{M}=394.33\right)$ is one of the tests for detecting the antioxidant capacity of a sample accord- ing to the following scheme:

$$
D P P H^{*}+A H \rightarrow D P P H-H+A^{*}
$$

The results for the antioxidant activities measured by DPPH of the different parts of the studied pomegranate accessions are presented in Figure.
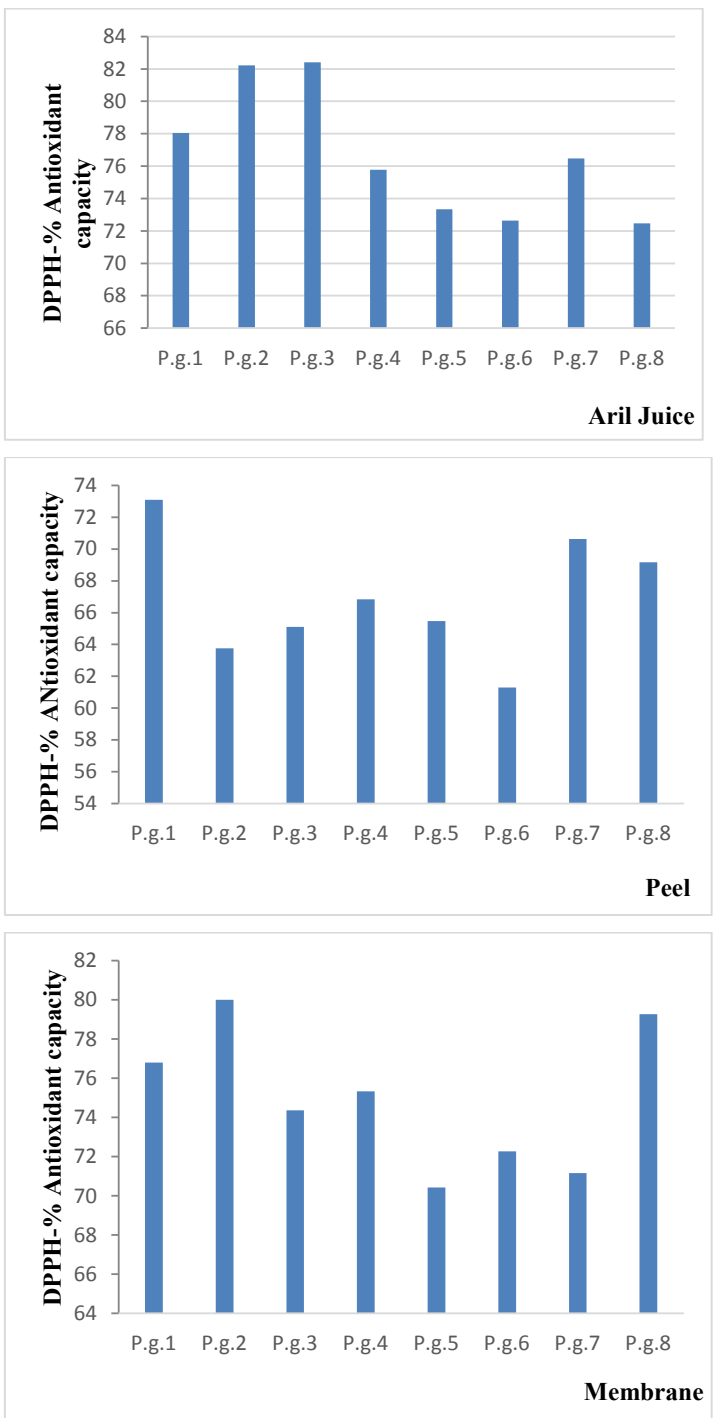

Figure. Antioxidant capacity of different parts of eight wild pomegranate accessions measured by DPPH method. The data represent the mean of three replicates from each part of accessions. 
In this study, the differences in antioxidant capacity among the different parts of pomegranate accessions were statistically significant and the values ranged from $61.3 \%$ to $82.4 \%$. The hierarchy for antioxidant capacity was as following: aril juice $>$ membrane $>$ peel. This order was different than that reported for Peruvian pomegranates, both phenolic compounds and antioxidant activities were in the order as aril juice $<$ peel $<$ membrane. [Fischer, Kammerer, 2011].

Based on our results, pomegranate aril juice can be identified as a fruit with potential antioxidant capacity, which can be explained by the higher composition of polyphenols in its composition.

The results of this study will contribute to the assessment of wild pomegranate biodiversity and allow to detect samples with high quality characteristics of fruits for potential commercial production of medicinal and cosmetic products obtained from this plant, as well as food additives. The different characteristics measured in the fruits from different areas suggest that environmental conditions in different areas of Azerbaijan influence the fruit quality. It opens the way to further investigation aimed at understanding what are the best cultivation conditions of such wild type varieties for not losing their functional quality.

\section{REFERENCES}

Ainsworth E.A., Gillespie K.M. (2007) Estimation of total phenolic content and other oxidation substrates in plant tissues using Folin-Ciocalteu reagent. $\mathrm{Na}$ ture Protocols, 2(4): 875-877.

Akbarpour V., Hemmati K., Sharifani M. (2009) Physical and chemical properties of pomegranate (Punica granatum L.) fruit in maturation stage. AmericanEurasian J. Agric. \& Environ. Sci. 6 (4): 411-416.

Cuccioloni M., Mozzicafreddo M., Sparapani L., Spina M., Eleuteri A.M., Fioretti E., Angeletti M. (2009) Pomegranate fruit components modulate human thrombin. Fitoterapia, 80: 301-305.

De Nigris F., Williams-Ignarro S., Lerman L.O., Crimi E., Botti C., Mansueto G., D’Armiento F.P., De Rosa G., Sica V., Ignarro L.J. (2005) Beneficial effects of pomegranate juice on oxidation sensitive genes and endothelial nitric oxide synthase capacity at sites of perturbed shear stress. Proc. Natl. Acad. Sci. USA, 102(13): 4896-4901.

Drogoudi P.D., Tsipouridis C. (2005) Physical and Chemical Characteristics of Pomegranates. HORTSCIENCE, 40(5): 1200-1203.

Elfalleh W., Tlili N., Nasri N., Yahia Y., Hannachi H.,
Chaira N., Ying M., Ferchichi A. (2011) Antioxidant capacities of phenolic compounds and tocopherols from Tunisian pomegranate (Punica granatum) fruits. J. Food Sci. 76 (5): 707-713.

Fernandes L., Pereira J.A., Lopez-Cortes I., Salazar D.M., Gonzalez-Alvarez J., Ramalhosa E. (2017) Physicochemical composition and antioxidant activity of several pomegranate (Punica granatum L.) cultivars grown in Spain. Eur Food Res Technol, 243: 1799-1814.

Fischer U.A., Carle R., Kammerer D.R. (2011) Identification and quantification of phenolic compounds from pomegranate (Punica granatum L.) peel, mesocarp, aril and differently produced juices by HPLCDAD-ESI/MS(n). Food Chem., 127(2): 807-21.

Gadže J., Voća S., Čmelik Z., Mustać I., Ercisli S., Radunić M. (2012) Physico-chemical characteristics of main pomegranate (Punica granatum L.) cultivars grown in Dalmatia region of Croatia, J. Appl. Bot. Food Qual. 206: 202-206.

Gil M.I., Tomás-Barberán F.A., Hess-Pierce B., Holcroft D.M., Kader A.A. (2000) Antioxidant activity of pomegranate juice and its relationship with phenolic composition and processing. J Agric Food Chem., 48(10): 4581-9.

Hirth M., Leiter A., Beck S.M., Schuchmann H.P. (2014) Effect of extrusion cooking process parameters on the retention of bilberry anthocyanins in starchbased food. J Food Eng, 125: 139-146.

Martínez J.J., Melgarejo P., Hernández F., Salazar D.M., Martínez R. (2006) Seed characterization of five new pomegranate varieties, Sci. Hort. 110: 241-246.

Novruzov E.N. (2010) Pigmenti reproduktivnix organov rasteniy i ix znaceniye. Baku: Elm, 309. (In Russian).

Pavez I.A.C. (2011) Caracterización física, química y sensorial de frutos de granado cv. Wonderful provenientes de tresregiones de Chile, Final course work. Universidad de Chile, Facultad de Ciencias Agronómicas, Santiago do Chile.

Poyrazoglu E., Gokmen V., Artik N., (2002) Organic acids and phenolic compounds in pomegranates $(\mathrm{Pu}$ nica granatum L.) grown in Turkey. J. Food Comp. Anal. 15: 567-575.

Raduníc M., Špika M.J., Ban S.G., Gadze J., DiázPérez J.C., MacLean D. (2015) Physical and chemical properties of pomegranate fruit accessions from Croatia. Food Chem 177: 53-60.

Rajasekar D., Akoh C.C., Martino K.G., MacLean D.D. (2012) Physico-chemical characteristics of juice ex- 
tracted by blender and mechanical press from pomegranate cultivars grown in Georgia. Food Chem 133: 1383-1393.

Rosenblat M., Aviram M. (2006) Antioxidative properties of pomegranate: In vitro studies. In N.P. Seeram, R.N.Schulman \& D.Heber, Pomegranates: ancient roots to modern medicine. New York: CRC Press. pp. 31-43.

Sharova E.I. (2016) Bioantioksidanti rasteniy. SanktPeterburg: Izd-vo Sankt-Peterburgskogo universiteta, 140 s. (In Russia).

Viuda-Martos M., Fernández-López J., Pérez-Álvarez J.A. (2010) Pomegranate and its many functional components as related to human health: a review. Compr Rev Food Sci Food Saf. 9: 635-654.

Azərbaycanda bitən yabanı nar bitkisi meyvələrinin fiziki-kimyəvi xüsusiyyətləri, antioksidant fəallığı və şirə tərkibində üzvü birləşmələrin tədqiqi

\author{
Aydan M. Zeynalova \\ Eldar N. Novruzov \\ AMEA Botanika Institutu, Badamdar şossesi 40, Bakl, AZ1004, Azərbaycan
}

\section{Biancaelena Maserti}

İtaliya Milli Tadqiqat Şurasının Davamlı Bitki Mühafizasi İnstitutu

Nar meyvələri bioloji aktiv komponentlərin zəngin mənbəyidir. $\mathrm{Bu}$ kimyəvi maddələr bitkinin müxtəlif hissələrində (ekzokarp, mezokarp, toxum və giləsində) toplanır. Yabanı nar meyvələri tərkibində çoxlu miqdarda potensial əhəmiyyətli bioloji fəal maddələr saxlayır. Yabanı nar nümunələrini toplamaq məqsədi ilə Azərbaycanın səkkiz rayonunda çöl tədqiqatları aparılmışdır. $\mathrm{Bu}$ məqalədə Azərbaycanın müxtəlif bölgələrində bitən yaban1 nar bitkisinin ekzokarp, mezokarp, meyvə şirəsinin fiziki xassələri və antioksidant qabiliyyətinin nəticələri, eləcə də bir nümunədə fenol birləşmələrin və antosianların keyfiyyət və kəmiyyət tərkibinin öyrənilməsinin nəticələri öz əksini tapmıșdır. P.g. 1 tərkibində olan bioloji aktiv maddələrin tədqiqi göstərdi ki, şirədə antosianlardan sianidin-3,5diqlukozidə (34.65\%), narın qabığında isə -epikatexin $(67.23 \mathrm{mq} / \mathrm{kq})$ polifenoluna daha çox rast gəlinir. $\mathrm{Bu}$ tədqiqatın nəticələri yabanı narın biomüxtəlifliyinin qiymətləndirilməsinə, yüksək keyfiyyətli xüsusiyyətlərə malik nümunələrin aşkar edilməsinə və bu nümunələrindən potensial kommersiya istehsalı məqsədi ilə müalicəvi və kosmetik məhsulların, həmçinin qida əlavələrinin istehsal edilməsinə kömək edəcəkdir. Açar sözlor: Punica granatum L., sorbost radikalların söndürücüsü, fenol birlaşmalari, antosianlar

\section{Исследование физико-химических} характеристик, антиоксидантной активности и состава органических соединений сока плодов дикого граната, произрастающего в Азербайджане

\section{Айдан М. Зейналова \\ Эльдар Н. Новрузов}

Институт Ботаники НАНА, Бадамдар 40, Баку, АZ1004,Азербайджан

\section{Бианкаелена Масерти}

Институт по устойчивой защчите растений, НИС, Италия

Плоды граната являются богатым источником биологически активных компонентов. Эти фитохимические вещества накапливаются в разных частях плода (экзокарп, мезокарп, семена, зерна). Дикорастущие виды граната содержат в плодах огромное количество потенциальных биологически активных соединений. В связи с этим в восьми районах Азербайджана были проведены полевые исследования по сбору образцов дикого граната. В этой работе приведены результаты о физических свойствах и антиоксидантной активности экзокарпа, мезокарпа и сока восьми дикорастущих образцов граната, произрастающих в различных регионах Азербайджана, а также результаты качественной и количественной оценки фенольных соединений и антоцианов в составе одного образца. Исследование биологически активных компонентов в составе P.g.1 показало, что цианидин-3,5-диглюкозид (34.65\%) был преобладаюшщим антоциановым пигментом сока, а -эпикатехин - наиболее распространенным полифенолом (67.23 мг/кг) в гранатовой кожуре. Результаты этого исследования будут способствовать оценке биоразнообразия дикого граната и позволят обнаружить образцы с высокими качественными характеристиками плодов для потенциального коммерческого производства лекарственных и косметических средств, а также пищевых добавок из плодов данного растения.

Ключевые слова: Punica granatum L., тушители свободных радикалов, фенольные компоненты, антоичаны 